\title{
The Value of a River
}

\section{J. Stephen Lansing, Philip S. Lansing and Juliet S. Erazo}

\section{Introduction}

How should society value resources that are not goods or services in the marketplace, but rather what economists used to call "free gifts of Nature"? Some natural processes have obvious economic significance: a free flowing river may provide habitat for commercially valuable species such as fish, shellfish or wildfowl. Less obvious, but equally tangible benefits from a wild river include the transport of sediments and nutrients that sustain biological communities. For example, tidal estuaries at the mouths of rivers are among the most productive aquatic ecosystems, providing a habitat for many species. Some have calculable economic value; others are a few steps away from us on the food chain. Yet if we are to harvest shrimp, oysters or fish, the estuary as a whole must continue to function as an integrated biotic community.

Put into a pipe, a river can also drive turbines to produce electric power whose immediate commercial value is undoubtedly higher than the pounds of fish, shellfish or waterfowl produced by the same river in its wild state. If we allow our notion of value to be defined exclusively by market value, we must always prefer to put rivers in pipes. The absurdity of such conclusions has led some economists and ecologists to search for better ways to quantify the "non-market value" of natural resources. ${ }^{1}$ Howard Odum's attempts to find a common framework for ecology and economics in thermodynamics are well known to systems ecologists, but his approach remains highly controversial. ${ }^{2}$ Alternatively, economists such as N. Georgescu-Roegen have proposed a "bio-economic" perspective based on assigning economic values to biological processes. ${ }^{3}$ For example, it is possible to estimate the value of the work done by ecological systems in terms of the cost of performing the same tasks using artificial substitutes. This approach has provided useful insights into such topics as the economic value of estuaries in waste disposal ${ }^{4}$, but it fails to capture the effects of complex biochemical processes that may extend far beyond the local area. For example, how should we quantify the economic value of trace metals carried by rivers to the open ocean? Does the river perform an economic service by transporting materials essential for the growth of phytoplankton and fish? Rather than going through the analytic contortions that would be necessary to attach dollar values to the full array of natural biochemical processes, it may be more sensible to recognize that

1. Cf. Farnworth, Edward G., T.H. Tidrick, C.F. Jordan and W.M. Smathers, 1981: The value of natural ecosystems: an economic and ecological framework. Environ. Conserv. 8:275-282; Sinden, John A. and A.C. Worrell, 1979: Unpriced Values: Decisions without Market Prices. New York: Wiley Interscience.

2. Odum, Howard T. and Elizabeth C. Odum, Energy Basis for Man and Nature. New York: McGraw Hill, 1981.

3. Nicholas Georgescu-Roegen, Energy and Economic Myths: Institutional and Analytical Economic Essays. New York: Pergamon Press, 1976.

4. Westman, W.E. How much are nature's services worth?, Science 197 (1977):960-964. 
the value of resources like rivers may not be fully calculable from within the horizons of conventional economic theory.

For the moment, the question of which natural processes or habitats are counted as valuable depends very much on who does the counting. The subject of this paper is a comparison of the value of a river to two groups, an Indian tribe and a utility company. In a sense, both view the river as a form of natural capital, a "gift of Nature" that provides resources of great value. But a conflict arises because the same river cannot simultaneously sustain wildlife habitat and drive the turbines of a hydropower plant. The Skokomish river was once the largest and most productive salmon river in Puget Sound. It originates in a small $(640 \mathrm{~km} 2)$, steep drainage (maximum elevation $2000 \mathrm{~m}$ ) on the rainy southeast slope of the Olympic mountains in western Washington state, and descends through mountainous, temperate rainforest, tracing a broad arc around the southern border of the Skokomish Indian reservation. In 1930 the City of Tacoma built two dams on the North Fork of the river, and diverted the flow into a pipe to drive a hydropower plant located on the reservation.

"Skokomish" is an Anglicized version of the Twana Indian word sqoqc.'bes, "People of the River". The "People of the River" opposed the construction of the dams and for over half a century have sought to return the river to its wild state. But their efforts have been hampered by the problem of translating their conceptions of the value of the river into the language of Western economics. The Skokomish case provides a particularly vivid example of how two societies can attach quite different values to the same physical resources. Such cases remind us that "value" is not a measureable physical property, but a social construction. Asked to define the value of a riverine resource such as salmon, an economist might investigate the price per pound at dockside or in the supermarket. But when asked the same question, a Umatilla Indian answered "How can I tell what the salmon are worth? The salmon define who I am. What else can I say."

It would be easy to conclude that the value of the river to the tribe simply cannot be determined from within the framework of Western economics; and indeed this thesis has often been advanced by attorneys for the utility company. But an assessment of the value of the river based entirely on its power to drive turbines is no more than a book-keeping convenience, illustrating not the power but the limitations of conventional economic analysis. Clearly, we need to find ways to think about the value of natural resources or "natural capital" that can accomodate complex ecological and social processes. The aim of this paper is to describe an analytical framework within which it is possible to assess the value of the Skokomish river as a form of "natural capital" to the Skokomish people. It will be shown that "natural capital" includes all that is encompassed by the concept of "social capital" defined by R. Putnam (1995) as "features of social organization such as networks, norms and social trust that facilitate coordination and cooperation for mutual benefit," but goes beyond social capital in that it requires the presence of certain ecosystem functions in order to accumulate. This assessment may serve two ends; first by providing an indication of the benefits that could be obtained by returning the river to its natural channel, and second by developing a method to estimate the magnitude of the losses sustained by the tribe, which from time immemorial had fished for salmon in the river, hunted for elk and waterfowl along its banks, gathered shellfish and grasses for baskets at its estuary, and sought for sacred visions and religious experiences at sacred sites along its course. 


\section{The river as a form of natural capital for the tribe}

An analysis of the value of riverine resources to the Skokomish before the hydropower diversion properly begins with the question of what those resources were, and how they were appropriated. The Skokomish regard the valley of the North Fork as the home of their ancestors, an idea which recently received archaeological support with the discovery of prehistoric village sites that were inundated by the flooding of Lake Cushman caused by the construction of the first power dam. ${ }^{5}$ In the nineteenth century the valley was also a major village site. The valley was the center for many important resources for the Skokomish, including flocks of waterfowl, large herds of elk that wintered in the valley, and many kinds of useful plants including ironwood, yew, bear grass, berries and cedar. A detailed picture of the importance of these resources for the Skokomish is provided by the work of William Elmendorf. Elmendorf was an anthropologist who conducted fieldwork among the Skokomish for nearly twenty years, and published a comprehensive ethnographic monograph on The Structure of Twana Culture in 1960. Many of Elmendorf's informants spoke to him about their activities in the valley before the dams were built: hunting for deer, elk, bear, wolf and marmots in the mountains, spearing ducks and geese from canoes in the river delta, and fishing for salmon and steelhead at the falls and in the river. The lake, waterfalls and mountain slopes were also important as sites for guardian spirit questing, a subject to which we will return.

The tidal estuary at the mouth of the river on Hood Canal was also a major natural resource for the Skokomish. The abundant shellfish present at the estuary were particularly valuable because they were stationary and available year round. Along with shellfish collection, other important activities included spearing and trolling for salmon and bottom fish, hunting for wildfowl with spears and nets, and harvesting of sweetgrass, cattail and other plant materials for baskets and containers. The estuary was also an important sacred site for the Twana Secret Society.

The third major riverine resource for the Skokomish was of course the river itself, as a habitat for anandromous fish. The Skokomish developed an extensive knowledge of the habits and what we would now term the ecology of all five species of salmon and steelhead, which arrive at the river in a more-or-less orderly sequence of "salmon runs" extending virtually the year-round. ${ }^{6}$ At the height of the salmon runs, vast quantities of fish were available. Maximizing the potential of this resource required a combination of technological and social innovations. If the salmon were to do more than provide for the subsistence needs of individual households, several problems needed to be solved: how to catch many fish in a short time, how to store the surplus that could not be consumed immediately, and how to convert that perishable surplus into wealth. The same problems

5. The age of these sites was estimated at between 5000 to 8000 years old based on the style of artifacts found and their similarity to other presumed "Olcott" sites in the Pacific Northwest (Gary Wessen, unpublished report to the Federal Energy Regulatory Commission, March 1990:194.

6. Spring chinook entered the Skokomish river in April, followed by summer steelhead, sockeye, fall chinook and early chum, and in alternate years, pink salmon. Beginning in late September and extending as late as early February, the river had large runs of coho and late chum. Winter steelhead appeared about November. 
exist for commercial fishermen today, who solve them by using large boats equipped with machine-operated gill nets, and selling the fish in the marketplace.

The Skokomish developed a wide variety of fishing techiques, including trolling, spearing, gaffing, trapping, set-lining and gill-netting. Some techniques were suited for fishing by individuals or small groups. The most effective method for taking salmon, however, was the construction of weirs spanning the river, which were set up by entire village communities during the salmon runs and carefully managed so that a surplus of fish could be caught without fatally interrupting the spawning cycle. ${ }^{7}$ There were at least three major weir sites in operation on the Skokomish river at the time of the Treaty of Point No Point. ${ }^{8}$ These weirs made it possible to catch far more fish than the community could consume. Most of the fish were preserved by smoking or drying. Fish oil and seal fat were stored in seal or porpoise bladders, while dried fish was stored in baskets made from cedar bark and roots and grasses from the river valley and estuary.

Thus the ability of the Indians to obtain a regular surplus of salmon depended on two types of technology: communal weirs and various systems used to catch the fish, and smoke-houses and containers used to preserve them. Effective use of this technology required the participation of large social units, which Elmendorf calls villages or "winterhouse groups":

Fishing weirs in the Skokomish river were the communal property of the members of a winter-house group who seasonally erected them. However, although all male members of a village were responsible for the construction and maintenance of a weir, sections of the weir platform and the suspended dip nets used there were individually owned...A large portion of any catch was distributed gratis to fellow villagers in any case. ${ }^{9}$

Without these communal weirs and an effective technology for storage and preservation, fishing would have remained a subsistence technology carried on by households, and only a fraction of the actual Twana population could have been supported by this resource. The high population densities, stratified social structure and complex ceremonial life which characterize traditional Twana culture are the products of an economic adaptation based on the collective management of riverine resources by the "villages" or "winter house groups". What were these groups?

The Twana language has no term for the nuclear family or household unit. ${ }^{10}$ Instead, the major social unit recognized by the Twana was the group of kinsmen and slaves who occupied the large winter joint-family houses. These groups or "villages" were called scel.a in the Twana language. According to Elmendorf, scel.a "referred to an entire

7. A row of removable lattice screens or sections was held against the tripod weir structure on the upstream side by the force of the current. One or more of these sections could be removed for a time each day or night to allow the salmon to continue upstream to their spawning grounds. Cf. William W. Elmendorf, The Structure of Twana Culture. Washington State University Research Studies Monographic Supplement 2:i-xiv, 1-576. Pullman: Washington State University Press, 1960:65-66.

8. U.S. vs. Washington, 384 F. Supp. 312 (1974):377: "They maintained at least three important weir sites on the Skokomish river during the 1850's."

9. Elmendorf 1960:269.

10. Elmendorf 1960:348. 
bilaterally reckoned line or lineage, a series of ancestors and descendants". ${ }^{11}$ Twana social organization was thus technically a form of kinship organization which anthropologists call a deme: a clan-like group of persons who reside together and are related to one another by marriage or by common descent through either of their parents. ${ }^{12}$ Twana demes functioned as corporate groups, whose joint estate included weir sites on the river and weirs themselves, as well as the large wooden building that served as their joint residence. Demes were socially stratified into three classes: upper class, commoners, and "slaves". ${ }^{13}$ Characteristically, even though "slaves" were descended from different kin groups, all residents of a winter village were regarded as members of the deme. The largest Twana demes in existence at the time of the treaty negotiations were located at the weir-sites along the Skokomish river. ${ }^{14}$

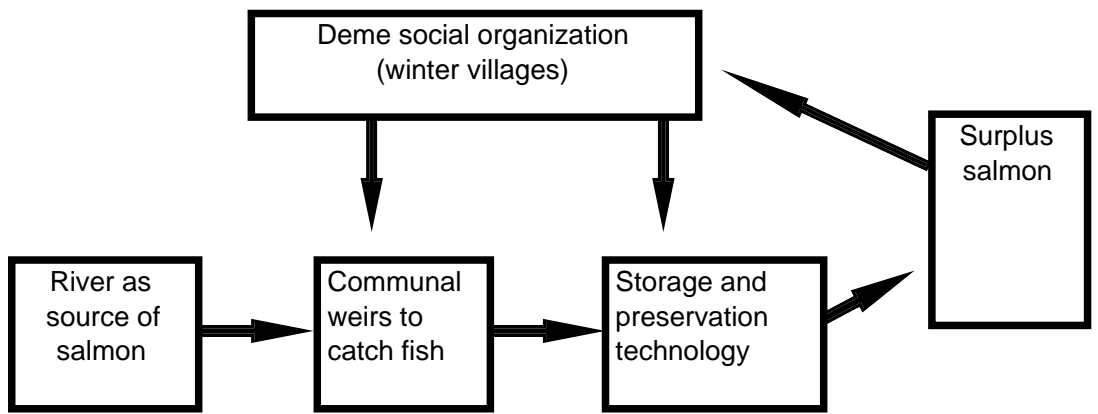

Figure 1: The social organization of the Skokomish salmon fishery.

During the spring and summer, members of demes dispersed in small family groups to their hunting, fishing and gathering territories, which included the entire drainage basin of the Hood Canal. In late summer the demes reassembled themselves in the "winter villages" at strategic locations along the rivers, in time for the salmon runs. The availability of the salmon made these large settlements possible, but it is equally true that the social organization of the deme created the weirs that made it possible to harvest a surplus of salmon. ${ }^{15}$

\section{Elmendorf 1960:348.}

12. Demes are distinguished from clans by the fact that membership in a clan is based on stipulated unilinear descent, while in demes descent is bilateral. Cf. George P.Murdock, Social Structure. New York: MacMillan, 1949:63. Referring to Coast Salish cultures in general, Joseph G. Jorgensen observed that "The joint practices of local exogamy and virilocality produce "patridemes", i.e., cognatic kin groups approximating the structure of lineages but based on filiation rather than descent." Joseph G. Jorgensen, Salish Language and Culture. Bloomington, Indiana: Indiana University Language Science Monographs, 1969:80.

13. "Slaves" in Twana society were war captives or the descendants of war captives, according to Elmendorf (1960:344).

14. Elmendorf 1960:3.

15. "..the families within a household cooperated in certain types of subsistence or ceremonial activities, especially those requiring a great deal of labor or the accumulation of vast amounts of wealth." Bruce G. Miller and Daniel L. Boxberger, Creating Chiefdoms: The Puget Sound Case, Ethnohistory Vol. 41, No. 2 (Spring 1994):270. 
Only a portion of the surplus salmon was needed for winter consumption in the villages. The remainder was exchanged via long-distance trading networks for items of wealth that could serve as gifts. This exchange network extended across the Cascade mountains ${ }^{16}$, as described by Gibbs:

The trade between the two districts was once considerable. The western Indians sold slaves, haikwa, kamas, dried clams \&c., and received in return mountain-sheep's wool, porcupine's quills, and embroidery, the grass from which they manufactured thread, and even dried salmon, the product of the Yakima fisheries being preferred to that of the Sound. ${ }^{17}$

The wealth items acquired through the trading network circulated in intra-and intercommunity exchanges which were the principal focus of social and ceremonial life among the Skokomish, as well as other Coastal Salish tribes. Elmendorf emphasizes that a surplus of fish was sought not as a source of food, but because of its role in a complex system of ritualized exchanges that were the foundation of the social and spiritual life of the community.

Winter feasting and heightened social activity were not merely matters of utilizing leisure made possible by the existence of preserved-food stores. In the Twana view these winter activities, particularly spirit dancing and its accompanying food distribution, were the necessities of life for which abundant food stores had to be put aside. Informants repeatedly expressed this view. "The real reason", said Frank Allen, "why people worked so hard in the summer and put aside all that food-more than they needed-was to feed their c'sa'lt (guardian spirits), when they came to them in winter." 18

In Twana society, individuals gained prestige and social status not by hoarding up their surpluses, but rather by generously giving goods away, in a manner that signified the incorporation of other people. According to the Twana concept of the relationship of humanity to the natural world, the continuation of human life required humans to kill sentient beings whom they considered to be, beneath their animal skins or guises, persons like themselves. For the Salmon People, the Elk People and the other animal species were regarded as sharing a common origin with humanity. As the anthropologist Marshall Sahlins observes:

Indeed the lives of people and game or fish are interdependent; for if the animals willingly give themselves to the Indians, it is because the Indians know how to assure the rebirth of their prey through the ritual aspects they accord the remains-a cycle that passes through a human phase when the animal is consumed as food. ${ }^{19}$

Such beliefs ensured that the social function of the winter villages extended beyond the annual creation of the communal salmon weirs. Each community also took responsibility

16. George Gibbs, Tribes of Western Washington and Northwestern Oregon. Contributions to North American Ethnology 1:157-241. Department of the Interior, Washington D.C.:169.

17. Gibbs 1877:170.

18. Elmendorf 1960:311.

19. Sahlins 1994:436. 
for enforcing rules against the pollution of the river, since this could interfere with the annual journeys of the Salmon People. It is reported that even when communities were feuding, the weirs were regularly opened to allow the fish to continue their journey upstream. In the autumn, at the height of the salmon run, villages held intercommunity potlatch feasts $\left(\right.$ siwad). ${ }^{20}$ Local surpluses of food were traded through an extensive exchange network to acquire items of wealth that could serve as gifts, whose bestowal was the main business of such feasts. The value of these wealth items was ranked, using double-fathom strands of dentalium shells as the units of value. In the siwad feasts, members of the upper class presented wealth items to important people from other communities, transforming the wealth generated by their mastery of the salmon fishery into personal status. Foodstuffs such as salmon were never treated as wealth for the purpose of these ceremonial gifts, although a lavish outlay of food was expected at the termination of a feast. ${ }^{21}$

For the sponsors of the siwad feasts, the ability to bestow rich gifts was proof of the potency of the powers they had acquired from their animal guardian-spirits. These powers were sought by individuals in vision quests in the mountains. Guardian spirits (also called "wealth-power spirits") gave power-songs to their chosen human representatives, and these songs were sung by the sponsors at the culmination of the siwad feasts. One became a member of the upper class by using the "wealth-powers" acquired from one's guardian spirits to accumulate wealth, and ultimately by transforming this wealth into prestige by giving it away in competitive feasting. While such feasts served to validate the upperclass status of the feast giver, they also helped to maintain social bonds between villages throughout Twana territory. The ties created by the feast cycles were further strengthened by marriages between upper-class individuals belonging to different demes. According to Elmendorf's informants, members of neighboring tribes were also frequently included in the cycles of feasts and marriage alliances. The social bonds thus created had important practical consequences. During the spring and summer, members of Twana demes were able to move freely over the entire Twana territory. Warfare existed in the Twana world, but only in the form of raids on their villages by distant tribes. Twana demes did not make war on one another, or on the neighboring tribes who participated in the feast cycles. Elmendorf noted that the Twana practiced only defensive warfare, and "in all accounts the raiding enemy was defeated by defensive action". ${ }^{22}$

We have emphasized that by extending social ties across the region, the feast cycles provided manifold practical benefits. But they also had symbolic or religious significance. Major rituals served to define Twana concepts of society in the context of the collective rites necessary to ensure the continuity of the world. For example, upper-class leaders of demes annually organized the "First Salmon" rituals, in which the bones of the first salmon caught were ceremoniously sent downriver to ensure the return of the souls of the Salmon People to their villages across the western ocean. ${ }^{23}$ Similarly, the entire community bore the responsibility to enforce rules against polluting the river which might harm the Salmon People in their journey upstream. Twana demes were at once social, economic and ritual units, whose prosperity depended on their fruitful connection to the

20. Elmendorf 1960: 338.

21. Elmendorf 1960:331.

22. Elmendorf 1960:465.

23. Elmendorf 1960:118-9. 
life-giving powers of the natural world. These powers were conceived as animal guardianspirits, who were actually human beings in their own countries. In Twana myths, the animals tell the people to treat them well and to remember that they are "just like people". Elemendorf's informants spoke of "the time when we were animals", before the world capsized, noting that "if the people aren't good, the animals know that there will be another [transformation or "capsize" of the world]". 24

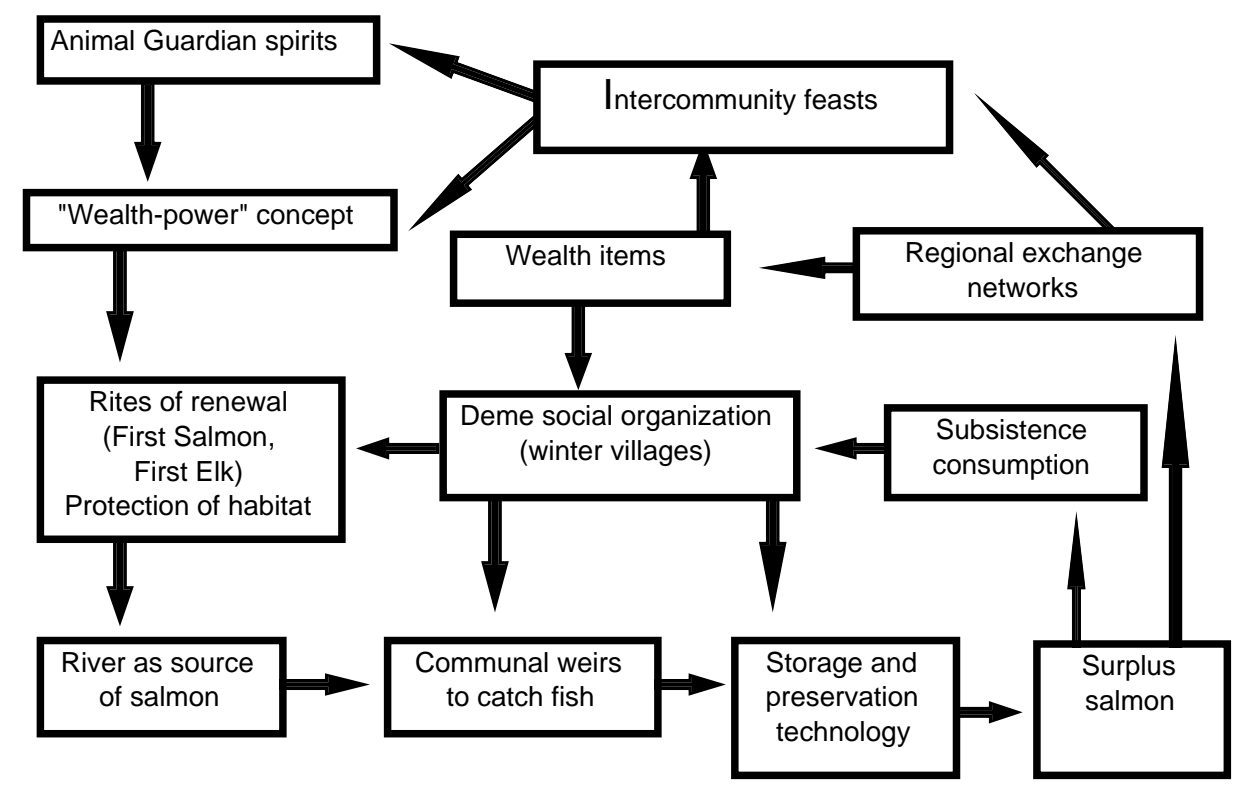

Figure 2: The salmon surplus is transformed into social ties between demes.

To sum up, from the Twana perspective the willingness of the Salmon People to come to their weirs was a sign of the good will of powerful "wealth-power" spirits possessed by the leaders of the deme. "Wealth-power" essentially meant the willingness of animals to be captured and eaten, a power that was conferred to worthy individuals (the leaders of demes) who demonstrated their gratitude and respect for this sacrifice. Valuable wealth items were thus tokens or proofs of the worthiness of the leaders of a deme to receive the sacrifices of the animals, and human greatness was achieved by bestowing such tokens as gifts on one's rivals. Sociologically, the major use of the surpluses of salmon sought by the demes was to acquire the wealth items which fueled the cycles of gift-giving and competitive exchange by which social alliances were extended across the entire Twana territory. ${ }^{25}$

\section{Post-reservation use of riverine resources}

In pre-reservation times, the Skokomish River provided winter-village homes for about half the Twana population, while the rest of the population was dispersed throughout the Hood Canal drainage basin. After the reservation was created in 1859, villages outside the

\section{Elmendorf 1960:20-21.}


reservation had to be abandoned. Surprisingly, the total number of people living along the Skokomish river was probably larger in 1800 than in 1870, because the Twana population was devastated in the nineteenth century by diseases such as smallpox, for which the Indians lacked natural immunity.

The merging of the Twana villages into a single tribal community was facilitated by the bilateral kinship system of the demes, which extended kinship ties between villages, and the traditional pattern of alliances between demes sustained by the feast cycle. Elmendorf's informants report that great "potlatch" feasts and gift presentations occurred in the 1860s as one by one the formerly independent demes abandoned their winter village sites and moved to the reservation. ${ }^{26}$ The tribal council was given legal responsibility for the management of the reservation, replacing the authority formerly held by the leaders of demes in each of the prereservation winter villages.

In the post-Treaty era (e.g. after 1859), fishing continued to be the preferred occupation of the majority of Skokomish men. Hunting, fishing and gathering activities continued along the North Fork, and the tribal government took over the function of stewardship over these resources. Redistribution of the entire Twana population to a single territory meant that fishing resources which were formerly controlled by Skokomish demes had to be reallocated. This change in fishing rights was facilitated by a change in fishing technology, as gill nets operated by individual fishermen replaced the old communal weirs as the primary method for harvesting salmon. Rather than leading to a loss of control by the tribe, this change actually enhanced the role of the tribal council in management of riverine resources. Successful use of gill nets depends on placing the nets in favorable locations on river eddies. The location of these eddy sites is a crucial issue for fishermen, and minor disputes are common. When gill nets replace the communal weirs, the tribal government assumed responsibility for adjudicating these disputes. It was agreed that rights to eddy sites for the salmon runs could be passed down along the lines of kinship by inheritance, and today some eddy sites have remained in the same families for over a hundred years.

In summary, the creation of the Skokomish reservation led to a major reallocation of resources. Demes which had formerly controlled weir-sites along all the rivers on the west side of Hood Canal coalesced into a single coresidential tribe, whose riverine resources were confined to a single river. The tribal government took over the functions of resource

25. Swezey and Heizer make a similar argument for the role of ritual (especially the First Salmon rites) in the management of salmonid resources among California Indians:...the anadromous fish resource in Native California was originally a seasonally abundant and renewable commodity which required intelligent and competent organization and control of fishing practices to ensure efficient harvest, especially during the spring migration of king salmon. Through the spring or summer salmon ceremony, ritual specialists directed and controlled fishing and dam building activities, regulated the opening of the salmon fishing season, and managed the use of the spawning runs, in many ways increasing the potential effectiveness with which native populations utilized the salmon resource. Sean L. Swezey and Robert F. Heizer, Ritual Management of Salmonid Fish Resources in California, in Thomas C. Blackburn and Kat Anderson, ed., Before the Wilderness:Environmental Management by Native Californians. Menlo Park, CA: Ballena Press, 1993:327.

26. Elmendorf 1960:273. 
management from the demes, and henceforth membership in the tribe, rather than any particular deme, conferred the right of access to the Skokomish River.

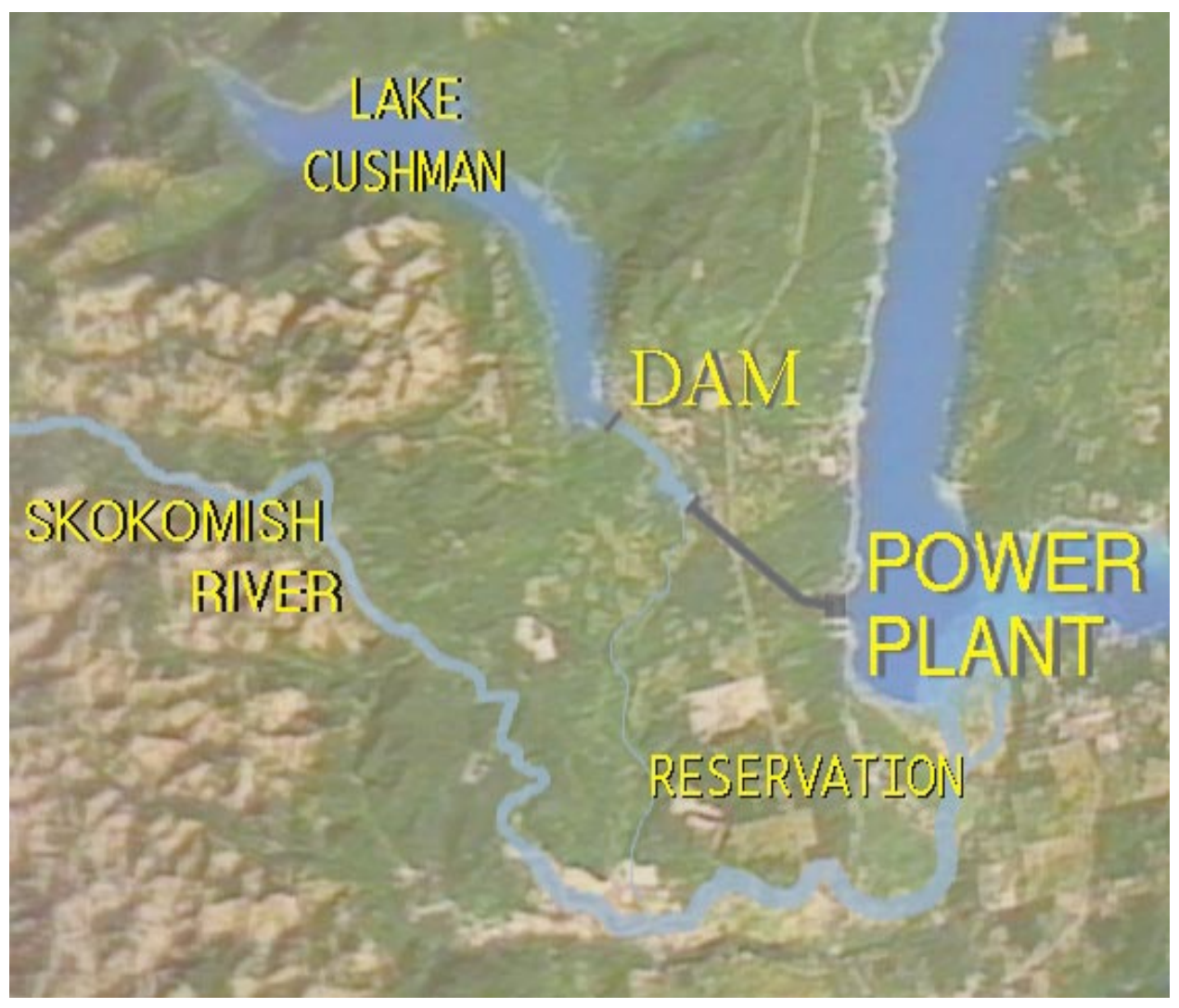

Figure 3: The Cushman Project.

\section{Effects of the Cushman Project}

A second major reallocation of resources began in the 1920's as a result of the Cushman Project, which consists of two dams and a hydroelectric power plant that utilize the flow of the North Fork of the Skokomish river (see Figure 3). The first dam was constructed in 1926 with facilities to generate power. The second and lowermost dam was completed in 1930, diverting the entire river out of its basin to a remote power plant on Hood Canal. This out-of-basin diversion dewatered the North Fork below the dam, and reduced by about $40 \%$ the flows in the main stem of the Skokomish river, which runs through the reservation into Hood Canal. The main power plant and transmission lines are located within the boundaries of the Skokomish reservation.

That the diversion of the North Fork would interfere with Indian fishing rights was recognized at the time the project was conceived, as indicated in a newspaper account from the Mason County Journal:

For a hydro-electric development, Tacoma proposes to acquire the Skokomish river power site, in Mason county, once considered by the City of Seattle. Before doing

so, Tacoma must come to a satisfactory arrangement with the Indian office regarding 
the Indian fishing rights in the Skokomish river, and regarding the crossing of the Skokomish reservation by the transmission line. ${ }^{27}$

The tribe acted immediately to oppose the project, according to a Seattle Times report of November 30, 1919:

Indians residing on the Skokomish reservation have leagued with the farmers in their fight on the grounds that drying up the river would deprive them of fishing privileges in a stream which was permanently guaranteed to their use under treaties.

A few weeks later, Indian Service agent W. B. Sams and Skokomish tribal members attended a hearing where Sams "presented a petition for this wards and read the original treaty, in which the Indians relinquished all their rights but that of fishing, and he urged that taking away the north fork waters would end their living from this source". ${ }^{28}$ Later news reports describe continuing protests against the dams, and in 1930 tribal members prepared to file lawsuits alleging violation of their treaty rights to the river. However, the judge dismissed the suits on the grounds that only the United States as guardian or trustee could sue for violations of tribal rights. ${ }^{29}$

The Cushman Project removed the North Fork from its banks, leaving at most a token flow, and also flooded the valley behind the main power dam. These disturbances set in motion a complex series of physical and biological changes, affecting many wildlife communities utilized by the Indians, ranging from elk and waterfowl to salmon, shrimp and shellfish populations. Some plant and animal communities were altogether lost, while others were greatly diminished. Before the dams were built, the North Fork of the Skokomish was the most productive salmon and steelhead river in the region. Newspaper articles from 1921-2 cite estimates by the Washington Department of Fisheries that the North Fork salmon and steelhead runs made up about 10 percent of the total annual catch for Puget Sound, and were worth between $\$ 100,000$ and $\$ 200,000$ per year at that time. ${ }^{30}$ Dewatering the North Fork led to drastic reductions in salmon and steelhead catches, and the permanent loss of several species of salmon. The loss of the flow from the North Fork also diminished the ability of the river to transport its sediment load to the estuary. Instead, sediment began to accumulate in the main stem of the river, causing progressive interference with salmon runs on the remaining tributaries of the river and also causing flooding. Meanwhile, the Skokomish estuary began to shrink, and shellfish harvests dwindled. ${ }^{31}$ Before the dams were built, steamships, tugs with barges and a side-wheeler regularly navigated up the main stem of the river, but today the river is so shallow that even a rowboat cannot always find passage up the main stem. Hydrologists attribute this dramatic change to the combined effects of the accumulation of sediment in the main stem channel since the dams were constructed, and the loss of flow from the North Fork.

27. Mason County Journal, January 16, 1920.

28. Seattle Times, December 12, 1929.

29. Mason County Journal, December 8, 1930.

30. Seith Times, March 17, 1922.

31. D.A. Jay and C.A. Simenstad, "Downstream Effects of Water Withdrawal in a Small, High-Gradient Basin: Erosion and Deposition on the Skokomish River Delta". Estuaries In Press, 1998. 
In summary, then, it is clear that the Cushman project led to a reduction of the productivity or value of the tribe's most important natural capital: the Skokomish river. We turn now to the question of how to assess the magnitude of this loss.

\section{The river as a form of natural capital}

In traditional Twana society, all individuals had the right to seek subsistence by hunting, fishing or gathering anywhere in the Twana territory. Similar privileges were generously granted to Indians from other tribes, and even to white settlers in the region. In contrast to this rather diffuse concept of the right of subsistence, Twana also inherited very specific rights and property through membership in a deme. The shared estate of Twana demes included real property such as large joint-family houses, smoke houses, weirs and fishing equipment. More importantly, demes owned the rights to weir-sites, and exercised stewardship over important local resources necessary for the economic well-being of the community. These constituted the estate or property of the deme as a corporate unit, which was clearly distinguished from the property of individuals. Like all pre-modern corporate kinship units, Twana demes were social and religious as well as productive units. Rights of deme members to use natural resources such as the salmon runs were linked with obligations (preventing pollution of the river, performing the necessary rites to ensure the perpetuation of animal species), that were fulfilled by the deme as a corporate unit.

After the creation of the Skokomish Indian Reservation, the surviving demes of the Twana people were merged into a single community. The informal bilateral kinship system of extended families persisted, but the management of the tribal estate was vested by treaty in the tribal government, which has continuously functioned in this capacity. The tribe's rights to the resources produced by the river have been repeatedly affirmed in the courts. For example, in U.S. vs. Washington the United States Supreme Court ruled that the vital importance of the fish to the Indians was repeatedly emphasized by both sides during the negotiations, and noted that the Governor's promises that the treaties would protect that source of food and commerce were crucial in obtaining the Indians' assent. This ruling referenced a 1905 decision by the Washington Supreme Court, that "...the right to resort to the fishing places in controversy was part of the larger rights possessed by the Indians, upon the exercise of which there was not a shadow of an impediment, and which were not less necessary to the existence of the Indians than the atmosphere they breathed." ${ }^{32}$ Thus the treaty and subsequent rulings explicitly guaranteed the tribe's rights to the resources generated by the river as a form of natural capital. By appropriating nearly the entire flow of the North Fork, the Cushman Project greatly diminished the value of the Skokomish river as wildlife habitat, and in so doing substantially reduced the value of the tribe's most valuable natural capital.

This loss of natural capital had a severe impact on the Skokomish people, both as individuals and as tribal members. Per capita income on the reservation is less than half the average for Washington state, and other economic indicators tell a similar story. ${ }^{33}$ Analytically, it is important to distinguish between the losses sustained by individuals, who on any given day will find fewer resources available, and the long-term erosion of the tribe itself as its collective social institutions are weakened. But how can the latter be determined? Is it possible to assess the long-term effects on the tribe of this steady erosion of its natural capital?

32. United States v. State of Washington 384 F. Supp. 312, 331 (1974). 
A possible answer to this question was recently proposed by an economist, Raul Fernandez, on the basis of his analysis of a case which closely parallels the one under consideration here. Fernandez was asked to conduct an economic analysis of a prosperous Indian tribe that fell into poverty after the appropriation of most of their water resources by a public utility. Fernandez' evaluation of the losses sustained by the Soboba tribe provides a useful benchmark for analyzing the effects of the Cushman project on the Skokomish.

Fernandez' research concerned the economic status of the Soboba Indian reservation, which consists of 5,056 acres on the southwestern slope of the San Jacinto Mountains in southern California. The reservation was created between 1883 and 1891 as a permanent home for the Soboba Band of Mission Indians. In 1933-39, a tunnel was constructed in the mountains beneath the reservation as part of the Colorado River Aqueduct. After the tunnel was built, the aquifers beneath the reservation began to drain into it, drying up natural springs and cienegas (seeps) on the reservation fed by these aquifers, and drastically reducing the quantity of irrigation water available on the reservation. By the early 1950s most fruit orchards were dead, and water had to be trucked to the reservation to meet household needs in the summer months. In 1976, the Indian Claims Commission ruled that the Soboba reservation had been transformed "from an oasis to a desert". 34

For over a century before the construction of the tunnel, the Soboba tribe had practiced irrigated agriculture. But as the water supply dwindled, some tribal members gradually turned to dry farming, while many others left the reservation. The community gradually disintegrated, "reduced to a factionalized group of distantly related families, lacking collective organization as an economic or cultural entity and plagued by pervasive political infighting". 35 Under the Winters doctrine the United States federal government is obliged to guarantee to recognized Indian tribes sufficient water for their consumption and agricultural needs. In the 1980s, representatives of the Soboba tribe successfully argued that the tribe as a whole had lost the natural capital represented by the presence of naturally-occuring water resources on the reservation.

The tribe initiated a series of court cases to seek return of their water supply and restitution for their losses. The latter included the value of the lost water itself, the cost of adequate water restoration, and the value of foregone agricultural production. In principle, all of these losses could be addressed by compensation to individuals. But the dewatering of the reservation also resulted in the impoverishment of the entire tribe, including the disappearance of most aspects of their kinship system. Fernandez was asked to estimate the magnitude of the social and cultural losses suffered by the tribe as a whole by the dewatering of the reservation. Based on the work of an anthropologist, Joseph

33. In 1990, according to U.S. Census records median household income on the reservation was $\$ 15,000$. In comparison, median household income in neighboring census blocks was \$28,823 for Tahuya, \$25,000 for Olympia, \$17,382 for Quilcene Bay, and \$27,970 for Southshore. Average per capita income on the reservation was $\$ 7,331$, compared to \$12,126, \$11,534, \$10,798 and \$13,974 for Tahuya, Olympia, Quilcene and Southshore respectively.

34. Indian Claims Commission 1976: Soboba Band of Mission Indians vs. the United States of America. 37 Indian Claims Commission 326, Docket No. 80-A, Washington, D.C.

35. Raul Fernandez 1987:3. 
Jorgensen, Fernandez observed that "when the Soboba community disappeared much more than income was lost", for the tribe suffered the loss of its major tribal social institutions and kinship system. Fernandez concluded that "since the demes were useful over and above their agricultural utility, compensation to individuals for the loss of water and agricultural production does not compensate them for the loss of their kinship system".

Fernandez suggested that the magnitude of the tribe's loss could be estimated by comparison with the cost of relocation projects abroad, when they involve the uprooting and relocation of an entire community (as for example when a community must be moved for a new dam). In such cases it is customary for institutions like the World Bank to require that major funding be allocated to sustain or rebuild the community's infrastructure, through the construction of facilities such as hospitals and schools. ${ }^{36}$ These expenditures are intended to help preserve or restore the social framework of the community. Following this logic, Fernandez proposed a budget for social reconstruction of the Soboba community, including a water project, hospital facility, meeting hall and sports facility, at a cost of $\$ 13,403,400$. He noted:

The Sobobans have fought indefatigably and collectively for the last 30 years to regain their language, communal observances and religion. They are on record as wishing, not merely a settlement, but the recovery of their community. To suggest cash payments to individuals as a form of settlement disregards the stated intentions of the Sobobans as a group and, implicitly, denies these Native Americans their birthright. $^{37}$

Fernandez' argument is equally applicable to the Skokomish case. Like the Sobobans, the Skokomish were once a tribe that prospered through the wise use of their natural resources. The dewatering of these reservations by public utility companies diminished the value of the tribe's natural capital, and led to the impoverishment of both communities. Tribal members sustain losses both as individual economic actors in a depleted landscape, and as members of a tribe weakened by the loss of a major portion of its collective estate.

\section{"Natural capital" versus contingent valuation}

We conclude with some final words on the concept of a river as "natural capital". This approach differs from the "contingent value" method commonly used by economists to assess nonmarket values. With respect to the latter, experimental and empirical studies have shown that respondents resist answering questions that ask them to place a monetary value on activities or places that contribute to their social capital (R.O. Putnam 1995). When they do respond, they often place values that appear implausibly large or small (R.C. Bishop et al. 1983). Fiske and Tetlock (1997) have investigated the reasons why individuals might find this process confusing or upsetting. They suggest four elementary models that give motivational and normative salience to social relationships. Although their approach seems somewhat oversimplified, it has the merit of showing that estimates

36. "For insight, the author looked to other countries, where when relocation is necessary, rural populations have sometimes been given the option of moving as whole communities. Relocation authorities might allocate funds for economic development, social services and housing for these groups" (Fernandez 1987:4).

37. Fernandez 1987: 8 . 
of monetary value are always embedded in a social context: a father who presented his children with a bill for their Thanksgiving dinner would be met with astonishment. The same sense of absurdity seems to be experienced by people asked to treat natural resources like rivers as though they were equivalent to amusement parks.

Viewing the river as a form of natural capital creates a more plausible context in which to make comparative estimates of its value. Rather than subjective estimates of the value of the river as an occasional source of recreation (or other income) to individuals, this approach directs our attention towards the river as the source of an ongoing stream of benefits. Like other forms of capital, biological habitat as natural capital produces economic benefits. But it is unlike other forms of capital in that the magnitude of these benefits is not directly proportionate to the quantity of capital (habitat size). In the 1970s biologists developed the Minimum Critical Size of Ecosystems Project (MCS) to study the relationship between habitat area and productivity (ability to sustain native plant and animal species) (E.O. Wilson 1995:225-226). This relationship is typically nonlinear: each species is embedded in a complex network of biochemical exchanges with other species and the environment, and depends on the continued functioning of the entire ecosystem for its own survival. In the Skokomish case, the loss of sediment-transport capacity in the river caused by the Cushman project led to progressive erosion of the Skokomish river estuary's most productive habitat, the low-intertidal and shallow subtidal margin of the delta. This reduction in critical habitat and associated loss of at least 20 percent of the highly productive eelgrass beds resulted in a significant reduction in the estuary's biological productivity and the productivity of the southern Hood Canal.

These changes have economic consequences. As noted earlier, the Skokomish was once the largest salmon river in the Hood Canal region of Puget Sound. Table 1 provides estimates of salmon runs in the North fork in the years immediately preceding the construction of the Cushman dams:

TABLE 1. Estimates of salmon runs in the North Fork Skokomish circa 1920.

\begin{tabular}{lccc}
\hline Species & Low estimate & Medium estimate & High estimate \\
Chinook & 30,000 & 45,000 & 60,000 \\
Coho & 30,000 & 60,000 & 90,000 \\
Chum & 50,000 & 60,000 & 90,000 \\
Pink & 30,000 & 65,000 & 100,000 \\
Sockeye & 10,000 & 15,000 & 20,000 \\
Steelhead & 4,000 & 12,000 & 20,000 \\
Totals & 154,000 & 257,000 & 290,000
\end{tabular}

\section{Source: Skokomish Fisheries Office.}

The river's estuary was also a vital habitat for many species of plants and animals. Diversion of the North Fork has, over the years, reduced the amount of sediment transported by the river to the delta. From 1930 to 1972 , bathymetric measurements indicated that the delta was reduced in size by approximately $1.4 \mathrm{~km}^{2}$. This is equivalent 
to an erosion rate of $0.01563 * \mathrm{yr}^{-1}$ during the period that flows from the North Fork were drastically reduced by the Cushman project diversions.

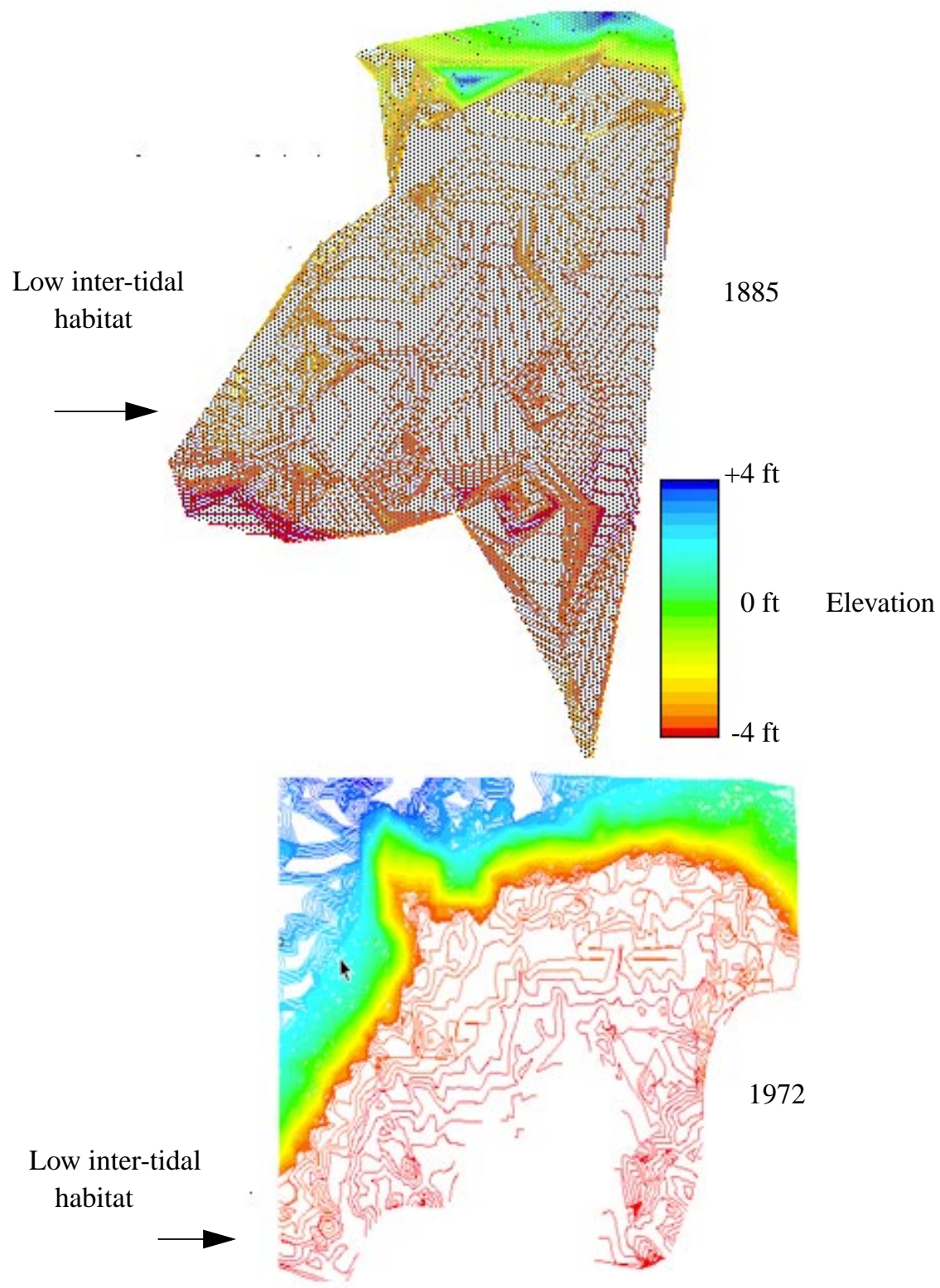

Figure 4. Bathymetry of Skokomish delta, 1885 and 1972. The shallow intertidal habitat is greatly reduced.

The causes of erosion and deposition on the delta have been investigated by D.A. Jay and C.A. Simenstad who conclude that erosion is due to loss of sediment transport capacity, caused by the diversion of the river for hydropower: 
"...because of the decreas in sediment transport capacity, a smaller percentage of the sediment brought into the main stem and inner delta is transported to the outer delta and deep water in Hood Canal than before the diversion. The sediment that is transported to the outer delta is on the average finer than before and more subject to subsequent erosion by winter storms and high tides. The result is a net accumulation of material on the inner delta and a net loss on the outer delta: that is, the delta has steepened" (D.A. Jay and C.A. Simenstad in Press).

The erosion of the most biologically productive shallow intertidal habitats are evident from comparisons of bathymetric surveys of the delta performed in 1885 and 1972 (Figure $4)^{38}$ The loss of shallow intertidal habitat at the Skokomish estuary reduces the total amount of organic carbon available for fish and wildlife, including all commercially valuable marine resources in Hood Canal. The total estuarine area of intertidal habitat supporting eelgrass and macroalgae in Hood Canal has been estimated at $37.6 \mathrm{~km}^{2}$. The estimated 3.4 percent loss in the most important habitat area in Hood canal caused by the diversion of the North Fork since 1930 has an economic impact because it reduces the total numbers of harvestable fish and shellfish. ${ }^{39}$ Restoring the river to its banks should have the opposite effect: gradually expanding the intertidal area by restoring normal sediment transport capacity.

In principle, it would be possible to relate this variation in habitat area to changes in the aggregate value over time of the commercially valuable wildlife partially supported by the Skokomish river. Such an estimate, is beyond the scope of this paper. But it would provide a more plausible starting point for the assessment of the value of the biological habitat supported by the river, than the contingent value method. The latter technique could possibly provide information about the recreational value of the river. But it would be very insensitive to the productive role of the river in creating wildlife habitat, which is central to the value of the river for the Skokomish people.

38. Declaration of David A. Jay, U.S.C. Section 1746, FERC project \#460, Federal Energy Regulatory Commission, 28 July 1994, "Effects of the Cushman Project on the Skokomish River and Estuary."

39. Simenstad used a stable carbon isotope $\left(\mathrm{c}^{13}\right)$ to elucidate potential sources and pathways of organic carbon in Hood Canal. He found that eelgrass and algae from intertidal ares of estuaries form the predominant source of carbon for many secondary consumers, including Dungeness crabs, juvenile chum and coho, flounder, sea perch, clams, crabs and mussels. He notes "Based on an estimated $11.5 \mathrm{~km}^{2}$ of intertidal eelgrass in all of Hood Canal's shoreline...I conservatively estimate that at least 3.4 percent or 3.393 metric tons of organic carbon has been lost to the total net Hood Canal production due to the Cushman Project.” Declaration of C.A. Simenstad, 28 U.S.C. Section 1746, FERC project \#460, Federal Energy Regulatory Commission, 28 July 1994, "Effects of the Cushman Hydroelectric Project on Ecological Contributions to Hood Canal”, 5 April 1995. 


\section{Conclusion}

We began with the question of how to evaluate the value of the Skokomish river as a form of "natural capital" for the Skokomish tribe. Attornies for the power company that presently manages the Cushman project have argued, so far successfully, that the "nonmarket value" of the river to the tribe is unknowable. A more reasonable approach would acknowledge the biological productivity of Skokomish river ecosystems as an essential component of the corporate estate of the Skokomish tribe, guaranteed by the treaty that established the reservation. The historical record is clear that the Skokomish Indian reservation was situated at the mouth of the Skokomish river so as to enable the tribe to make continuing use of the wildlife resources provided by the Skokomish river. Along with the reservation itself, these resources constituted the natural capital of the tribe.

The continuing diversion of the North Fork for hydropower creates two distinguishable categories of losses to the tribe, the first of which is instantaneous while the second is progressive. Instantaneous losses caused by the dams and the dewatering of the North Fork are caused by the disappearance of habitat, leading to reductions in the populations of plant and animal species that are used and valued by Skokomish tribal members. An example is the immediate disappearance of salmon on the North Fork caused by the removal of the river. We might think of these losses as reductions in immediate income derived from the river as natural capital: fewer fish and other wildlife. Thus, since the inception of the Cushman project, each individual tribal member has suffered a loss of access to riverine resources including wildlife such as fish, game, and wild plants, as well as the spiritual and recreational sites on the North Fork that were eliminated by the Cushman project.

The other costs to the tribe are analogous to losses in capital rather than immediate income. The dewatering of the North Fork generated continuing losses to tribal members due to reduced wildlife populations and the disappearance of valued sites along the river. Along with these losses to individual tribal members, the tribe as a whole was impoverished by the loss of a vital portion of its corporate estate. Like the Sobobans, the "People of the River" have endured a progressive weakening of their community caused by the disappearance of a valuable natural resource. As with the Soboban case, compensation for this loss could appropriately take the form of investments in the social and economic infrastructure of the tribe, such as health, education, social services, and the preservation of artistic and cultural traditions, to help restore the depleted value of tribal institutions. Of equal importance is investment in the restoration of the natural systems that formed the basis of the tribe's cultural traditions, and enabled the steady accumulation of natural capital. 


\section{References}

Bishop, R.C., Heberlain, T. and Kealy, M.J.

1983. Contingent valuation of environmental assets: comparisons with a simulated market. Natural Resources Journal 23: 618-633.

Elmendorf, W.W.

1960. The Structure of Twana culture. Pullman: Washington State University Research Studies Monographic Supplement.

Farnsworth, E.G., Tidrick, T.H., Jordan, C.F. \& Smathers, W.M.

1981. The value of natural ecosystems: An economic and ecological framework. Environmental Conservation 8: 275-282.

Fernandez, R.

1987. Evaluating the loss of kinship structures: A case study of North American Indians. Human Organization 46:1-9.

Fiske, A.P. \& Tetlock, P.E.

1997. Taboo trade-offs: Reactions to transactions that transgress the spheres of justice. Political Psychology 18: 255-297.

Georgescu-Roegen, N.

1976. Energy and economic myths: Institutional and analytical economic essays. NewYork: Pergamon Press.

Gibbs, G.

1877. Tribes of Western Washington and Northwestern Oregon. Contributions to North American Ethnology 1: 157-241.

Jay, D.A.

1994. "Effects of the Cushman Project on the Skokomish River and Estuary." Declaration to the Federal Energy Commission, FERC Project No. 460. 28 July .

Jay, D.A. \& Simenstad, C.A.

(In press). Downstream effects of water withdrawal in a small, high-gradient basin: Erosion and deposition on the Skokomish River Delta. Estuaries.

Jorgensen, J.G.

1969. Salish language and culture. Bloomington, Indiana: Indiana University Language Science Monographs.

Miller, B.G. \& Boxberger, D.L.

1994. Creating chiefdoms: The Puget Sound case. Ethnohistory 41(2): 270.

Murdock, G.P.

1949. Social structure. New York: MacMillan.

Odum, H.T. \& Odum, E.C.

1981. Energy basis for man and nature. New York: McGraw Hill.

Putnam, R.D.

1995. Bowling alone: America's declining social capital. Journal of Democracy 6: 6578.

Sahlins, M.

1994. The cosmology of capitalism. In N. Dirks, et al. (Eds.) Culture/ power / history.

Princeton, New Jersey: Princeton University Press. 
Simenstad, C.A.

1995. "Effects of the Cushman Hydroelectric Project on Ecological Contributions toHood Canal." Declaration to the Federal Energy Commission, FERC Project No.460. 5 April.

Sinden, J.A. \& Worrell, A.C.

1979. Unpriced values: Decisions without market prices. New York: Wiley Interscience.

Swezey, S.L. \& Heizer, R.F.

1993. Ritual management of salmonid fish resources in California. In T.C. Blackburn

\&K. Anderson (Eds.) Before the wilderness: environmental management by NativeCalifornians. Menlo Park, California: Ballena Press.

United States Indian Claims Commission.

1976. Soboba Band of Mission Indians vs. the United States of America Indian ClaimsCommission 37:326, Docket No. 80-A.

Wessen, G.

n.d. Unpublished report to the Federal Energy Regulatory Commission. March 1990.

Westman, W.E.

1977. How much are nature's services worth? Science 197: 960-964.

Wilson, E.O.

1992. The diversity of life. Cambridge: Harvard University Press.

\section{Abstract}

The Skokomish river was once the most productive salmon river in Puget Sound, but since 1926 the North Fork Skokomish has been diverted for hydropower. The Skokomish tribe has fought unsuccessfully to restore natural flows. At issue is the "non-market value" of the river's biological productivity. The value of the river as "natural capital" for the tribe is analyzed from an historical, ethnographic, and ecological perspective.

Keywords: non-market values, natural capital, salmon, Pacific Northwest, Skokomish, riverine ecology, ecosystem management.

\section{Resumé}

Le fleuve Skokomish était au paravent le fleuve la plus productif en saumon de Puget Sound, mais depuis 1926 le cours de la forche nord du Skokomish a été détournée pour produire de l'énergie. La tribu Skokomish a combattu sans succès pour restaurer l'écoulement naturel. Une des questions fondamentales est la valeur non-marchande de la productivité biologique du fleuve. La valeur du fleuve en tant que "capital naturel" pour la tribu est examinée en suivant une perspective historique, ethonographique et écologique.

Les Mots-clefs: valeurs non-marchande, capital naturel, saumon, Pacific Northwest, Skokomish, écologie riveraine, aménagement d'écosystèmes. 


\section{Resumen}

El Río Skokomish era antes el más productivo para salmón en la Bahía de Puget, pero desde 1926 la confluencia norte del Río Skokomish ha sido canalizado para generar poder hidroelectico. La tribu Skokomish ha luchado sin éxisto por restorar el agua a su curso natural. La question es cuál es el valor que tiene de la productividad biologica del río afuera su valor del mercado. El valor del río para la tribu, como una forma de "capital natural," es analizado del punto de vista histórico, etnográfico, y ecológico.

Palabras cláves: valor afuera del mercado, capital natural, noroeste pacifico, Skokomish, ecologia ribera, manejo del ecosistema. 
The Value of a River

This page is intentionally left blank 